\title{
STATE AGE PROTECTION LAWS AND THE AGE DISCRIMINATION IN EMPLOYMENT ACT
}

\author{
Joanna Lahey* \\ CRR WP 2006-24 \\ Released: November 2006 \\ Draft Submitted: July 2006 \\ Center for Retirement Research at Boston College \\ 258 Hammond Street \\ Chestnut Hill, MA 02467 \\ Tel: 617-552-1762 Fax: 617-552-0191 \\ www.bc.edu/crr
}

* Joanna Lahey is an assistant professor of public policy at Texas A\&M University. The findings and conclusions expressed are solely those of the author and do not represent the views of the Center for Retirement Research at Boston College. Thanks to Liz Oltmans Ananat, Josh Angrist, David Autor, M. Rose Barlow, Dora Costa, Mary Lee Cozad, Joni Hersch, Dan Hungerman, Christine Jolls, Guy Michaels, Olivia Mitchell, Sendhil Mullainathan, Jim Poterba, J. J. Prescott, Peter Siegelman, Ebonya Washington and participants at SOLE, the UIUC labor seminar and at the MIT labor and public finance lunches for helpful comments. Thanks also to Lisa Bell and Jennifer Greengold for excellent research assistance in updating and correcting the list of state laws from original sources and to Luu Nguyen and YiDing Yu for error checking. Funding from the National Institute on Aging, through Grant Number T32-AG00186 to the National Bureau of Economic Research for their aging pre-doctoral and post-doctoral fellowships, is gratefully acknowledged. Opinions and errors are my own.

(c) 2006, by Joanna Lahey. All rights reserved. Short sections of text, not to exceed two paragraphs, may be quoted without explicit permission provided that full credit, including (C) notice, is given to the source. 


\title{
About the Center for Retirement Research
}

The Center for Retirement Research at Boston College, part of a consortium that includes parallel centers at the University of Michigan and the National Bureau of Economic Research, was established in 1998 through a grant from the Social Security Administration. The goals of the Center are to promote research on retirement issues, to transmit new findings to the policy community and the public, to help train new scholars, and to broaden access to valuable data sources. Through these initiatives, the Center hopes to forge a strong link between the academic and policy communities around an issue of critical importance to the nation's future.

\author{
Center for Retirement Research at Boston College \\ 258 Hammond Street \\ Chestnut Hill, MA 02467 \\ phone: 617- 552- 1762 fax: 617- 552- 0191 \\ e-mail: crr@bc.edu \\ www.bc.edu/crr
}

\author{
Affiliated Institutions: \\ American Enterprise Institute \\ The Brookings Institution \\ Center for Strategic and International Studies \\ Massachusetts Institute of Technology \\ Syracuse University \\ Urban Institute
}




\begin{abstract}
Some anti-discrimination laws have the perverse effect of harming the very class they were meant to protect. This paper provides evidence that age discrimination laws belong to this perverse class. It exploits an unusual aspect of the policy for enforcement of the federal 1968 Age Discrimination in Employment Act (ADEA), which made filing an age discrimination claim less burdensome in some states than in others. After the enforcement of the federal law, white male workers over age 50 in states where the federal government allowed 300 days to file a discrimination complaint worked between 1 and 1.5 fewer weeks per year than did workers in states without laws. These men were also .3 percentage points more likely to be retired and .2 percentage points less likely to be hired. These findings suggest that in an anti-age discrimination environment, firms seek to avoid litigation through means not intended by the legislation—by not employing older workers in the first place.
\end{abstract}




\section{Introduction}

The 1968 Age Discrimination in Employment Act (ADEA) prohibits discrimination against older workers in hiring, laying off, firing, compensation, or other conditions of employment. The original motivation behind the ADEA was lawmakers' concern that employers incorrectly perceive older workers to be less productive or are unwilling to make modest adjustments to accommodate these workers. The U.S. Department of Labor Report (1965) that examines the need for older worker protection states that employers are making "assumptions about the effect of age on the ability to do a job when there is in fact no basis for these assumptions.” Lawmakers today seek to encourage labor force participation to ease the projected Social Security budgetary shortfalls and they worry that capable older workers are not granted job opportunities (Butrica et al. 2006). Although the labor market fortunes of older workers tend to be better than those of younger workers, older workers are less likely to find employment after being separated from a job (Chan and Stevens 1999, 2001, 2004, Diamond and Hausman 1984). When older workers do find new jobs, they are clustered into a smaller set of industries and occupations than are younger workers (Hutchens 1988).

The question this paper addresses is whether age discrimination legislation itself, both at the federal and state levels, has had negative consequences on employment options for older workers that were unintended by the original framers of the law. There are three margins on which these laws can affect older workers' employment levels: firing, hiring, and retirement. Employment may increase or decrease for older workers depending on which margins are most affected by the laws. First, a firm affected by these laws will be unlikely to fire an older worker outright for fear of a lawsuit. 
However, it is very difficult to prove or detect discrimination in hiring, and thus employers may choose not to hire older workers who will be difficult to fire, especially because class action lawsuits were not allowed under the ADEA during the time period studied (Donohue and Siegelman 1991, O’Meara 1989). Finally, because the line between unemployment and retirement tends to blur for older workers (Choi 2002), firms that wish to avoid being sued may increase retirement incentives for these workers (rather than fire them outright), thus decreasing the employment of older workers. On first examination, increasing retirement incentives for older workers may seem to benefit both the workers and the company. However, if the increase in retirement incentives is coupled with an increased threat of layoffs, then the resulting increase in retirement may not be entirely voluntary. Because it is difficult for older workers to find new employment, the possibility of losing one's job without the retirement package is a worse prospect for older workers, who may feel that they have no choice but to accept the retirement package, than for younger workers, who have a higher probability of finding new employment (Lahey 2005). Indeed, Schuster and Miller (1984) find that 31 percent of cases brought under the ADEA before 1981 involved involuntary retirement.

This paper uses state age discrimination laws matched by state and year to the March monthly Current Population Survey (CPS) to look at retirement outcomes for protected workers. To investigate the impact of hiring and job separation outcomes for older workers, I constructed measures of separations and accessions (hires) by matching CPS rotation groups as in Bleakley et al. (1999). My empirical strategy uses the assumption that, because of an unusual provision in the federal law, workers in states with their own age discrimination laws are more likely to be affected by the federal 
ADEA law. Under this law, workers in states with age discrimination laws have almost twice as long to file. Additionally, in states with these laws, state Fair Employment Practices (FEP) offices may be able to process claims more quickly than the Equal Employment Opportunity Commission (EEOC), though this is not guaranteed. Thus, I compare workers who are affected by the law in states with laws and workers who are not affected by the law in states with laws to those who are in states without laws.

I find that age discrimination laws, including state laws, had no negative effects (using CPS March monthly data) on labor market outcomes before the 1968 federal law was enforced and given to the EEOC in the late 1970s. Even after enforcement, these laws also did not affect older women or minorities, possibly because minorities are granted stronger protections under the Civil Rights Act of 1964 and this cohort of older women in general did not file age discrimination lawsuits. ${ }^{1}$ After the 1979 enforcement, white male workers over the age of 50 in states with age discrimination laws worked fewer weeks per year and were less likely to be hired or separated from their jobs, but were more likely to be retired (perhaps involuntarily). ${ }^{2}$ These findings suggest that firms do not wish to hire older workers most affected by the law, are afraid to fire older workers, but remove older workers through retirement incentives in states where lawsuits are less of a hurdle for the worker.

Although the hope is that anti-discrimination laws will raise employment and wages for members of protected groups, a number of studies suggest that these laws may

\footnotetext{
${ }^{1}$ Although the decision of whether to file under the Civil Rights Act or the Age Discrimination in Employment Act (or both) is dependent on the individual circumstances of a case, from the hiring employer's perspective, race and gender may be more salient features than age, or employers may have different beliefs about the propensity to sue of older women and older minorities than older white men. Gregory (2001) argues that women did not sue under the ADEA in the earlier time period because with their lower wages and, unlike Title VII, no allowance for punitive or "pain and suffering" damages, women did not stand to gain much from an ADEA lawsuit.

${ }^{2}$ I also look at wage outcomes, but do not find any effect of the laws on wages.
} 
be coupled with side-effects not intended by the law-makers. For example, Gruber (1994) finds that although mandates that stipulated that childbirth be covered comprehensively in health insurance plans did not change employment levels, they caused a decrease in wages of women of child-bearing age. Similarly, DeLiere (2000), Acemoglu and Angrist (2001), and Jolls and Prescott (2004), among others, find a negative effect on employment prospects for disabled workers following the 1990 Americans with Disabilities Act. My findings suggest that the Age Discrimination in Employment Act falls into this class of laws with unintended consequences.

The remainder of the paper is organized as follows. Section 2 provides background information on the legal environment surrounding age discrimination laws, including a brief literature review. Section 3 explains my empirical strategy. Section 4 gives information on data and descriptive statistics. Section 5 presents results, including robustness checks. Section 6 concludes.

\section{Background}

The first state age discrimination law came on the books in 1903 in Colorado. By 1960, eight states had age discrimination laws. ${ }^{3}$ Although the U.S. Civil Service had banned maximum hiring ages in federal employment in 1956 and legislated against age discrimination in federal contracting in 1964, federal legislation protecting older workers overall did not appear until 1967 with the introduction of the Age Discrimination in Employment Act, or ADEA. The 1967 ADEA prohibited age-based discrimination for those aged 40-65 in firms with 20 or more workers. Under this act, employers were

\footnotetext{
${ }^{3}$ I have not been able to find any pattern to the introduction of these laws. States with and without laws look very similar across measured characteristics. In the robustness checks portion of the results section I run a test as if states with laws had introduced them 5 years earlier and find no evidence of any underlying differences between states that introduce and have not yet introduced laws.
} 
barred from using age in hiring, laying off, firing, compensation, or other conditions of employment. It also prohibited employers from using age-specific language in advertising. Although Adams (2004) finds a small positive effect of the introduction of this law, most researchers agree that the federal law had little effect until the 1978 amendment to the ADEA (Neumark and Stock 1999, O’Meara 1989). ${ }^{4}$ In 1978, Congress extended the protected age group to 40-70 and eliminated mandatory retirement for most federal employees. A second major change, in terms of enforcement, came in 1979 when the Department of Labor (and, for federal employment, the U.S. Civil Service Commission) gave administrative responsibility to the U.S. Equal Employment Opportunity Commission (EEOC). Most researchers agree that this change strengthened the power of the ADEA because the change came with an increase in resources and an increase in "pattern and practice" lawsuits (Neumark 2001). ${ }^{5}$

In 1986, Congress amended the ADEA to eliminate the upper protected age range for age discrimination, effectively eliminating mandatory retirement for all except in cases where a safety issue related to age might be considered a bona fide occupational qualification (BFOQ), such as for pilots, or where the existence of job tenure would impose an undue hardship on the employer, such as for professors. ${ }^{6}$ In 1990, the Older

\footnotetext{
${ }^{4}$ Neumark and Stock (1999) note that the existence of the law may have given plaintiffs higher standing in court even in the absence of enforcement mechanisms. Additionally, O’Meara (1989) suggests that the 1978 Supreme Court ruling (codified in the 1978 amendment to the law) that those bringing lawsuits based on age should have the right to a jury trial may have had a stronger effect than congressional changes to the law itself or its transfer to the EEOC, because juries are more likely than judges to find for the plaintiff in these cases (Hersch and Viscusi 2004). Hersch (2006) finds that civil litigation cases in which jury trials are demanded are 5.5 percentage points more likely to settle without a trial than are cases where the right is waived.

${ }^{5}$ Although some law scholars argue that EEOC pattern and practice lawsuits are irrelevant, publicity surrounding the laws and the lawsuits could be the driving force behind differences in employer reaction to age laws. O’Meara (1989) argues that while the 1964 law was passed with little publicity, the events surrounding the 1978 amendment and enforcement were well publicized.

${ }^{6}$ Ashenfelter and Card (2000) looked at the end of mandatory retirement for college faculty.
} 
Workers Benefits Protection Act (OWBPA) imposed restrictions on the financial tools employers could use to induce worker retirement (Neumark 2001, O’Meara 1989).

The procedure to file a claim under the ADEA differs importantly between states with and without their own age discrimination laws. Because the EEOC has a large backlog of cases, it rarely prosecutes claims itself. Instead, if a state has its own age discrimination statutes, then the ADEA requires the claimant to file with the state Fair Employment Practices (FEP) office within 300 days. ${ }^{7}$ Otherwise, in states that do not have statutes, the claimant must file with the EEOC within 180 days. ${ }^{8}$ The EEOC can then dismiss the claim, at which point the claimant may pursue a civil action in court, or the EEOC can seek to settle or mediate. If the settlement or mediation is unsuccessful, the EEOC can then sue, or if it chooses not to sue, the claimant may sue (Neumark 2001). Over 95 percent of employment discrimination cases are brought by private attorneys, not the EEOC (Gregory 2001). ${ }^{9}$ Because claimants have more time to file if their state has a law, and, because the claim may be processed faster by the state FEP than the backlogged

\footnotetext{
${ }^{7}$ In almost all cases after 1978, the state FEP office came into being after the age discrimination law (according to each state's FEP office). A regression that codes the state law as taking effect when the state has both FEP office and age discrimination law finds very similar results to those presented in the paper. Chen (2005) gives information on the 26 states that had FEP offices prior to 1964.

8 "For ADEA charges, only state laws extend the filing limit to 300 days." http://www.eeoc.gov/charge/ overview_charge_filing.html. This difference in time limits favoring those with state legislation, regardless of the number of days required to file by the state legislation itself may seem strange to those more familiar with other protection laws. It is thought that the original intent of the legislation was to allow plaintiffs 180 days to file with their local state agency, in the hope that the state agency would settle the matter within the remaining 120 days before involving the federal government. In practice, however, lags have been longer and courts have interpreted the law literally, allowing the plaintiff the full 300 days to file with both the state and federal agencies. Unlike Title VII plaintiffs, ADEA plaintiffs do not have to wait between filing with the state and the EEOC; there is no Rule of Mohasco for ADEA claims. Thus whereas a Title VII plaintiff could file with a state agency on day 240 at the latest in order to file on day 300 with the EEOC, an ADEA plaintiff could file with both on day 300 . Today most FEP offices have work-sharing agreements with the EEOC so that only one application is needed to file with both offices (O’Meara 1989, Lindemann and Kadue 2003).

${ }^{9}$ As a side-note, only 8 percent of employment discrimination cases filed in federal court proceed to the trial stage (Gregory 2001).
} 
EEOC, claimants in states with age discrimination laws have less of a hurdle to suing than do claimants in states without those laws. ${ }^{10}$

Awards are limited to “make whole” status and lawyers' fees, that is, the award returns the plaintiff to where he or she would have been had he or she not been the subject of discrimination. These awards include hiring, reinstatement or promotion, back pay, and restoration of benefits and lawyers' fees. Attorney's fees often make up the bulk of the payment by the firm. Unlike race cases covered by the Civil Rights Act (CRA), additional damages are not awarded except in cases involving willful violation of law and these are limited to twice the amount of actual damages (Gregory 2001, Levine 1988, O’Meara 1989). ${ }^{11}$ Thus, among those who believe that they have been discriminated against during this time period, suing under the CRA may be more attractive to women and minorities, with their lower salaries on average, but the ADEA is the best option for older white men. ${ }^{12}$

\footnotetext{
${ }^{10}$ Ideally, we would like to know whether or not the number of lawsuits and out-of-court settlements went up in states with and without laws. Unfortunately, during the time periods studied, the EEOC did not keep track of age discrimination lawsuits, and out-of-court settlements are even more difficult to find information on. The published studies that examine trends in age discrimination lawsuits, such as Schuster and Miller (1984), pull random samples from Lexis-Nexis searches. Additionally, with protection laws, it is not clear that the number of lawsuits should go up in response to a change in the legal climate if, as I find, firms respond through diminished hiring of older workers where discrimination detection and prosecution is difficult and by limiting behaviors such as firing that could more easily result in lawsuits. All that would be needed to produce this change in firm behavior is publicity about the law, something that may be more prevalent in states with their own laws, not an increase in actual lawsuits.

${ }^{11}$ Gender cases did not allow punitive damages until the passage of the 1991 Civil Rights Act.

${ }^{12}$ The Americans with Disabilities Act was not introduced until 1991. Indeed, regardless of other lawsuit opportunities, the expected costs of bringing an age discrimination lawsuit do not outweigh the benefits unless the plaintiff had a reasonably large salary or has lost pension benefits. Joni Hersch (personal communication) has also suggested that lawyers may be unwilling to take cases on contingency fee unless the expected winnings are reasonably large and thus will not take on low paid female or minority clients for age cases. Although lawyer fees can be charged on top of the regular in-court settlement, the size of a contingency payment in an age discrimination case may be smaller for women and minority out-of-court settlements because the expected in-court winnings would be smaller.
} 
The majority of people who sue under the ADEA are white male middle managers or professionals over the age of $50 .{ }^{13}$ Employment termination in the form of wrongful discharge and involuntary retirement, not differential hiring, is the cause of most suits. It is thus possible that the ADEA acts as a form of employment protection. At the beginning of EEOC enforcement, 14 percent of claimants were women. By 1995 this number had risen to only 30 percent (Donohue and Siegelman 1991, Gregory 2001, Schuster and Miller 1984). As mentioned before, women and minorities stood to gain less from bringing an age discrimination lawsuit than did white men because of their lower lost potential earnings and pensions. In some cases they may have greater protection under the Civil Rights Act, which also allows punitive damages. Thus my identification strategy focuses on white men over the age of 50, who are most likely to sue under the law.

This paper is the first to examine the impact of the ADEA from its early years through a significant time period after its enforcement. It also uses yearly CPS data and examines the effects on many segments of the labor force, not just those over or under the age of retirement. Adams (2004) looks at the introduction of the federal law in 1968 and finds an increase in employment for those protected by the federal law and a decrease for those older than the protected ages. His identification strategy relies on the assumption that states with laws prior to the introduction of the ADEA are not affected by its passage, an assumption that may or may not be valid because the 1968 ADEA had no enforcement mechanism. There is also some question about the validity of the early CPS

\footnotetext{
${ }^{13}$ O’Meara (1989) has a literature review for the demographics of people who brought lawsuits under the ADEA, including Schuster and Miller (1984).
} 
that Adams uses in his pre-period. ${ }^{14}$ Neumark and Stock (1999) look at censuses from 1940 to 1980 , and thus have only one data point after the enforcement of the ADEA. ${ }^{15}$ The census may not be the best source of data to examine the impact of these laws because it cannot follow year to year changes.

The end of mandatory retirement in 1986 and 1994 has been more extensively studied than have other aspects of the ADEA. Till von Wachter (2002) looks at the shift of mandatory retirement to age 70 in 1978 and its end in 1986 using imputed probability of being covered by mandated retirement and finds that the labor force participation of workers age 65 and older increases by 10 to 20 percent in 1986. Mitchell and Luzadis (1988) find that in 1960, pension plans rewarded delayed retirement, but by the 1980s, union plans actively encouraged early retirement. However, non-union plans still rewarded delayed retirement. Ashenfelter and Card (2000) show that the abolition of retirement for college professors in 1994 reduced retirement for those age 70 and 71 . Although the end of mandatory retirement is important, it does not tell the story of the entire effect of the ADEA, particularly the consequences of this legislation on older workers wishing to be hired or promoted and the effects on workers who are over the age of 50 (and thus "old”) but too young for mandatory retirement to have affected them. This paper fills these gaps in the literature.

\footnotetext{
${ }^{14}$ According to the frequently asked questions on the Unicon website, www.unicon.com, CPS data prior to 1968 are not supported by the census bureau, have small sample sizes, little documentation, and are missing information. Additionally some of the questions on earnings were changed or recorded differently in 1968.

${ }^{15}$ I update Neumark and Stock's list of state laws for use in this paper. In some cases I made corrections, but these corrections to their list were for laws after 1980 and thus do not affect their results. The focus of Neumark and Stock (1999) is to test the effects of age discrimination laws on long-term Lazear contracts, confirming the hypothesis put forth in Jolls (1996) that the ADEA provides a commitment device for these contracts in the absence of perfect employee monitoring.
} 


\section{Empirical Strategy}

To study the effect of state age discrimination laws, I use an OLS Differences in Differences specification:

$$
\mathrm{y}_{\mathrm{it}}=\mathrm{X}_{\mathrm{i}} \beta_{1}+\beta_{2}\left(\mathrm{H}_{\mathrm{st}} * \mathrm{~A}_{\mathrm{i}}^{\text {over } 50}\right)+\beta_{3}\left(\mathrm{H}_{\mathrm{st}} * \mathrm{~A}_{\mathrm{i}}^{\text {under } 50}\right)+\theta_{\mathrm{t}}+\partial_{\mathrm{a}}+\varphi_{\mathrm{s}}+\zeta_{\mathrm{st}}+\varepsilon_{\text {ist }}
$$

where $\mathrm{i}$ denotes individuals and tenotes time; $\mathrm{y}_{\mathrm{it}}$ is either weeks worked, a dummy indicating employed, a dummy indicating retirement, a dummy indicating hired this month, or a dummy indicating being separated from a job this month; $\mathrm{X}_{\mathrm{i}}$ is a set of controls including a dummy for married and a dummy for high school graduate. $\mathrm{H}$ is an indicator that is equal to one if the state $s$ in which the individual resides has an age discrimination law in year t. $\mathrm{A}_{\mathrm{i}}^{\text {over50 }}$ is an indicator equal to one if the individual is over the age of 50 , and $A_{i}^{\text {under } 50}$ is an indicator equal to one if the individual is age 50 or under. $\theta_{\mathrm{t}}$ is a set of time dummies; $\varphi_{\mathrm{s}}$ is a set of state dummies; $\partial_{\mathrm{a}}$ is a full set of age dummies; and $\zeta_{\mathrm{st}}$ is a state specific linear time trend. The assumption behind this strategy is that it is easier for workers to sue, and thus to enforce age discrimination laws, in states that have their own age discrimination laws than in states that do not. Thus workers over the age of 50 in states with laws will be more affected than will workers in states without laws.

Equation (1) varies somewhat from the standard differences in differences equation, which would be:

$$
\mathrm{y}_{\mathrm{it}}=\mathrm{X}_{\mathrm{i}} \gamma_{1}+\gamma_{2}\left(\mathrm{H}_{\mathrm{st}}\right)+\gamma_{3}\left(\mathrm{H}_{\mathrm{st}} * \mathrm{~A}_{\mathrm{i}}^{\text {over } 50}\right)+\theta_{\mathrm{t}}+\varphi_{\mathrm{s}}+\partial_{\mathrm{a}}+\zeta_{\mathrm{st}}+\varepsilon_{\text {ist }}
$$

where $\gamma_{3}$ is the effect of the law on workers over the age of 50 compared to workers under the age of 50 in states with laws. This equation is equivalent to equation (1), in 
that $\beta_{2}=\gamma_{2}+\gamma_{3}$ and $\beta_{3}=\gamma_{2}$. The reason for using equation (1), which compares workers over and under the age of 50 in states with laws to workers in states without laws, as the specification, is that one can more clearly see the effects of the law on the two different age groups in the sample. $\beta_{2}$ is the effect of having a law on workers over the age of 50 and $\beta_{3}$ is the effect of having a law on workers age 50 and under, relative to workers in states without laws. Age 50 was chosen as the age cutoff because white men over 50 are most likely to sue under the law. ${ }^{16}$

A second possible way of identifying is through a Differences in Differences in Differences strategy using women as a second control group. Having lower salaries and less to gain from a lawsuit, these early cohorts of women are historically less litigious than are older men or women in later cohorts. Additionally, because women's attachment to the labor force is weaker than men's, employers may figure that women will leave or retire on their own before they become a liability due to their age. Thus employers may not see older women as constituting as much of a threat due to age discrimination laws as they do men. My strategy is:

$$
\begin{aligned}
& \mathrm{y}_{\mathrm{it}}=\mathrm{X}_{\mathrm{i}} \beta_{1}+\beta_{2}\left(\mathrm{M}_{\mathrm{i}} * \mathrm{H}_{\mathrm{st}} * \mathrm{~A}_{\mathrm{i}}^{\text {over } 50}\right)+\beta_{3}\left(\mathrm{M}_{\mathrm{i}} * \mathrm{H}_{\mathrm{st}} * \mathrm{~A}_{\mathrm{i}}^{\text {under } 50}\right)+\beta_{4}\left(\mathrm{M}_{\mathrm{i}} * \mathrm{~A}_{\mathrm{i}}^{\text {over } 50}\right)+ \\
& \beta_{5}\left(\mathrm{M}_{\mathrm{i}} * \mathrm{~A}_{\mathrm{i}}^{\text {under } 50}\right)+\beta_{6}\left(\mathrm{H}_{\mathrm{st}} * \mathrm{~A}_{\mathrm{i}}^{\text {over } 50}\right)+\beta_{7}\left(\mathrm{H}_{\mathrm{st}} * \mathrm{~A}_{\mathrm{i}}^{\text {under } 50}\right)+\theta_{\mathrm{t}}+\varphi_{\mathrm{s}}+\partial_{\mathrm{a}}+\zeta_{\mathrm{st}}+\varepsilon_{i s t}
\end{aligned}
$$

\footnotetext{
${ }^{16}$ Workers age 40 are generally not considered old. In fact, chief executive officers surveyed responded that on average age 43 represented the "peak productivity" year (Munk 1999). Employers may believe that the 30s and 40s may be an ideal age to hire a new worker: the worker has had a chance to develop general human capital and is ready to settle down and is thus worth training in firm specific human capital. It is likely that the age of 40 was chosen rather than age 50 by lawmakers because if age 50 had been chosen there would be mass firings of workers age 49 . By setting the minimum age at a point where firms valuation of the worker is much greater than a potential lawsuit, the law avoids this potential problem. Additionally, because workers of age 40 are generally employable, even if they have been discriminated against in terms of age, they are more likely to find a new job rather than to spend time and money on a costly lawsuit. Age 50, the age at which AARP membership begins and 5 years before many people vest their DB pensions, seems to be a reasonable cut-off point defining an "older worker" in hiring situations.
} 
where $\mathrm{i}$ denotes individuals, $\mathrm{t}$ denotes time; $\mathrm{y}_{\mathrm{it}}$ is either weeks worked, a dummy indicating employed, a dummy indicating retirement, a dummy indicating hired this month, or a dummy indicating being separated from a job this month; $\mathrm{M}_{\mathrm{i}}$ is an indicator that equals 1 if the individual is male. $\mathrm{H}_{\mathrm{st}}$ is an indicator that is equal to one if the state $\mathrm{s}$ in which the individual resides has an age discrimination law in year t. Variables $\mathrm{X}_{\mathrm{i}}$, $\mathrm{A}_{\mathrm{i}}^{\text {over } 50}, \mathrm{~A}_{\mathrm{i}}^{\text {under } 50}, \theta_{\mathrm{t}}, \varphi_{\mathrm{s}}, \partial_{\mathrm{a}}$, and $\zeta_{\mathrm{st}}$ are as defined in equation (1). The assumptions behind this strategy are that it is easier for workers to sue, and thus to enforce age discrimination laws, in states that have their own age discrimination laws than in states that do not, and that women are less likely to be affected by these laws than are men. Thus, men over the age of 50 in states with laws will be more affected than either workers in states without laws or than women.

Finally, I try a more stringent identification strategy in terms of possible state and time trends by allowing state times year effects:

$$
\mathrm{y}_{\mathrm{it}}=\beta_{1}\left(\mathrm{H}_{\mathrm{st}} * \mathrm{~A}_{\mathrm{i}}^{\text {over } 50}\right)+\theta_{\mathrm{t}}+\varphi_{\mathrm{s}}+\partial_{\mathrm{a}}+\varphi_{\mathrm{s}} * \theta_{\mathrm{t}}+\varepsilon_{\text {ist }}
$$

with variables defined as before.

\section{Data and Descriptive Statistics}

The first sample I use to look at the impact of age discrimination laws is drawn from the 1968-1991 March CPS and is limited to white men aged 25 to 85 . I break this set up into two smaller sets, one covering 1968-1977 and the other covering 1978-1991, because the Congressional committee reported on the ADEA in $1977^{17}$ (amendments followed in 1978 and enforcement by the EEOC in 1979), and because of changes in the

\footnotetext{
${ }^{17} \mathrm{http}: / /$ caselaw.lp.findlaw.com/scripts/getcase.pl?court=us\&vol=472\&invol=353
} 
CPS beginning in 1976. I limit to 1991 because the introduction of the ADA provides new protection to older workers. ${ }^{18}$ The impact of the ADEA on employment levels is evaluated by looking at data on weeks worked during the calendar year preceding the March income supplement. The impact on wages is measured using the average weekly earnings, computed using annual earnings data. After 1979, the CPS prompted respondents to be sure to include overtime pay, tips, bonuses, commissions, and money from employers other than the primary employer. ${ }^{19}$ The impact on retirement and labor force participation is measured using the self-reported retirement and labor force coding from the CPS employment status variable. The second sample I use is a matched monthly CPS. I follow the algorithm developed in Bleakley et al. (1999) to match job flow variables. These matched data allow me to measure the impact of the ADEA on hiring and job separation outcomes.

CPS questions about weeks worked and income refer to the previous year. The year reported in the tables and figures is the year in which the CPS was administered, not the year referred to in the questionnaire. Questions about labor force status and retirement refer to the respondent's main occupation in the previous week. From 1968 to 1976 in the early period, the CPS does not identify all states but groups some of them together. For state groups in which all states in the group have the same law status for the year, I code these as having or not having the law depending on status. If any state in the group does not have the same status as the others for the year, I drop these states for the years in which they disagree. The basis for state laws was taken from Neumark and Stock (1999) and checked against several secondary sources. When Neumark and Stock

\footnotetext{
${ }^{18}$ Stock and Beegle (2004) examine the interactions of the ADA and the ADEA after 1991 and find different effects on employment for protected workers by age.

${ }^{19}$ Results are robust to removing 1978 as a year from the wage regressions.
} 
(1999) disagreed with the secondary sources, these laws were checked against primary sources from Westlaw and from microfiche and hard copies of compiled state laws. Additionally, the list was updated for years not in Neumark and Stock using Monthly Law Review updates and Westlaw.

Descriptive statistics can be found in Table 1. As mentioned before, the universe is restricted to white males. As workers get older, they are less likely to be unemployed and more likely to be out of the labor force. The employment rate, weekly wage, and total income increase by age until age 45 in the early sample and age 50 in the later sample, after which they begin to drop. Men in the set are more likely to be married as they get older until their mid-50s in the early sample and mid-60s in the later sample. Older cohorts are also less likely to be high school graduates. Wage income and education levels are higher on average for workers in states with laws. Average weeks worked is larger for workers in states with laws in the early period but not in the later period. Men are more likely to claim to be retired in states with laws in the later period. ${ }^{20}$ Figure 2 shows the dates that states implemented their age protection laws. States without laws in the later period are more likely to be in the South. ${ }^{21}$

\section{Results}

\subsection{Employment, Wage, and Retirement Effects}

Figure 1 plots average weeks worked by white men aged 25 to 50 and those aged 51 to 85 who worked in states with and without laws for those who worked a positive number of hours. The number of weeks worked in Figure 1 is taken as the average of the

\footnotetext{
${ }^{20}$ All of the aforementioned differences between states with and without laws are significant at the 5 percent level with a t-test.

${ }^{21}$ Results in paper are robust when universe is limited to pre-1986 data.
} 
midpoint of intervalled weeks worked per year. The number of weeks worked by older men has been declining during this time period, although this decrease has leveled out in the 1980s. Older men in states with age discrimination laws work more weeks per year than do older men in states without laws until the late 1970s, when the two lines begin to look more similar, while those corresponding for the younger men retain the same trend. This convergence suggests that the possibility of a new enforcement mechanism may have had an effect before the enforcement actually came in place in 1979 in states that were more aware of age discrimination legislation. Weeks worked by younger men dropped as well from 1979 to 1982 and then increased through the rest of the 1980s. In general, younger men in states without laws worked more weeks per year than those in states with laws.

Table 2 reports ordinary least squares (OLS) estimates of equation (1). The universe is white men between the ages of 25 and 85, inclusive. The dependent variables are weeks worked, log weekly earnings, and retired. ${ }^{22}$ The controls in these regressions are dummies for married and high school graduate, and a set of age dummies, state dummies, and year dummies. ${ }^{23}$ Regressions are clustered on state. The coefficients of interest are havelaw*over50, which is the interaction of the observation being over age 50 and being in a state with a law, and havelaw*under50, which is the interaction of the observation being the age of 50 or under and being in a state with a law. ${ }^{24}$ The table also reports estimates from specifications including a linear time trend interacted with state.

\footnotetext{
22 The coefficient reported for retired is the marginal effect of the probit.

23 Adding college graduate instead of high school graduate as a control changes the coefficient on over50*havelaw to range between -1.045 without a state year trend to -1.37 with a state trend, compared to -1.5 and -1.16 respectively.

${ }^{24}$ Recall that people in states with laws have more time to file a claim and can work with the state FEP agency rather than directly with the EEOC; thus they have less of a hurdle to file a lawsuit. Even though
} 
The results in Table 2 suggest a substantial and statistically significant decline in weeks worked per year for people over the age of 50 after it was announced that the ADEA would begin to be enforced in $1978 .{ }^{25}$ For example, in Table 2A, columns 3 and 4 show a drop of between -1.1 and -1.5 weeks worked for older white men, those over 50 , in states with age discrimination laws and essentially no effect on white men under 50 in those states. In the early period, there is no effect on weeks worked for either older or younger workers, though this lack of finding may be due to measurement error in weeks worked per year, because prior to 1976 they were only reported in intervals.

Panel 2B of Table 2 reports estimates on log weekly wages of white men aged 25 to 50 and 51 to 85 in states with and without laws. Once state trends are added, there is no evidence of any effect on either older or younger workers in the early period, although again, because the variable, weekly wages, is manufactured from weeks worked and not all states are included in the early period, this finding may be an artifact of the data. ${ }^{26}$ Additionally, without state trends, there is a significant positive effect on wages of older workers in states with laws and the point estimate remains positive once trends are added. In the later period, there is a positive effect on wages of older workers in states with laws, but this effect is not statistically significant. Thus age discrimination laws may increase

the law covers workers over 40, in practice white men over the age of 50 are the most likely to sue. Some states with laws also protect workers in firms with fewer than 20 workers. Neumark and Stock (1999) code three states, Colorado, Georgia, and North Dakota as having "weak" laws in the post period. Coding these states as not having a law does not appreciably change the results; for example, the coefficient on weeks worked in Table 2A(3) changes from -1.5 to -1.2 and is still significant at the 5 percent level.

${ }^{25}$ Weeks worked variable includes zeros for people who did not work any weeks.

${ }^{26}$ No evidence is found for an effect in the early period using annual wages either, suggesting that the lack of an effect on weeks worked may be real and not just an artifact of the interval data and missing states. 
wages of older workers, but this wage effect is not significant once state trends are added. $^{27}$

Panel 2C reports estimates on self-reported retirement of white men over and under 50 in states with and without laws. Note that unlike the weeks worked and income questions, the retirement question is asked about the previous week, rather than the previous year. In the early period, the effect on retirement is small and insignificant for older workers, and negative and significant for younger workers. In the later period, older workers are .2 to .3 percentage points more likely to say they are retired in states with laws than are men in states without laws, though this effect is only marginally significant once state trends are added. ${ }^{28}$ This finding provides suggestive evidence that age discrimination laws encourage retirement in older workers. This effect could be emerging through two different channels. It could be that companies prefer to offer retirement packages to older workers rather than laying them off or firing them, thus decreasing the chance of a lawsuit. Alternatively, it could be that unemployed older workers who face decreased chances of re-employment prefer to refer to themselves as retired rather than unemployed.

\section{Robustness Checks}

Although Figure 1 suggests that the possibility of the enforcement of the federal age discrimination law may have affected employment of older workers in states with laws as early as 1977, when committees reported on the ADEA, an argument can be made for using the year 1978, when the enforcement was announced, or 1979, when the

\footnotetext{
${ }^{27}$ If there is a genuine positive effect on wages, it may be because, as is shown later, firms are less likely to either hire or fire older workers. Since firms often offer lower wages to new hires than to workers with long tenure, the average wage in this sample may go up.

${ }^{28}$ The base rate of retirement for all white men is .125 , and .325 for those over the age of 50 .
} 
enforcement actually took place, as the start year for the later period. Results using these later cut-off dates can be found in Table 3. Again, the age range refers to the dates the CPS was administered, and thus refers to the earlier year for questions on weeks worked and income. These results are substantively the same as those from 1978 to 1991, although in general the magnitude of the coefficients is somewhat smaller. Additionally, the results for weeks worked per year lose significance at the 5 percent level once state trends are included in the regression.

The age 85 was chosen as the top age in order to allow a generous top age specification while still eliminating possible outliers. The typical person who sues under the ADEA, however, is a white male between the ages of 50 and $59 .^{29}$ To test for sensitivity to the top age used, I run separate regressions with age universes topped at 75, 65, and 59. These results can be found in Table 4. Again, there is no evidence of an age discrimination law effect on relative wages for these smaller age universes. The magnitude of the coefficient of havelaw*over50 drops for both weeks worked per year and retirement as the age universe is trimmed, suggesting there might be a stronger effect on older workers. Weeks worked per year is no longer significant when state time trends are added once 75- to 84-year-olds are removed and loses significance entirely once the universe is restricted below 65, although this result is not unexpected because the universe is smaller. Retirement remains positive and significant for the 25- to 74-yearolds without state trends but drops when the range is restricted to those under 65 . Coefficient magnitudes are larger with older top age tails, suggesting that much of the effect of these laws is concentrated at later ages.

\footnotetext{
${ }^{29}$ Schuster and Miller (1984) find that 55 percent of plaintiffs they studied from 1968 to 1981 are aged fifty through fifty-nine. An EEOC study looking at different data from 1979 to 1983 found similar results by age (O’Meara 1989).
} 
Similar regressions shown in Table 5, looking at women and minority groups, found no effect of age discrimination laws on weeks worked. Protected minority groups are afforded greater protection under the Civil Rights Act (CRA) and can be awarded punitive damages in addition to "make whole" damages from the CRA, but not the ADEA and, with their lower average salaries, older women from these cohorts are not litigious. Thus employers may not worry about age for these groups as they are more likely to be sued under the CRA and would have to pay out a larger settlement under the CRA. Additionally, I may be finding no effect because employers may believe that, because women have weaker labor force attachment, they may leave before a lawsuit becomes an issue. Sample sizes for blacks are small and are even smaller for other minority groups and thus may not be big enough to pick up an effect of age laws. I do find a positive effect on weekly wages for black men of all ages in states with laws once state time trends are added in, but that may be a spurious result. I also find no effect on retirement for these groups.

Older white men in middle-management positions are most likely to sue. Therefore it may be of interest to break up the set by college education, since managers are more likely to be college educated. Columns 5 through 8 of Table 5 report results for white men by college graduation. In table $5 \mathrm{~A}$, results on weeks worked for both of these groups are very similar to those of the whole sample, with the coefficient of havelaw*over50 decreasing in magnitude and significance with state specific trends for the group of non-college graduates but increasing in magnitude and significance for those with a college education. If there is a state-specific time trend to weeks worked that varies by education, then this trend would suggest that age discrimination laws do hurt 
those in demographic groups that are more likely to sue. Table 5C shows similar results for claiming retirement as an outcome; older non-college graduates are significantly more likely to claim retirement without a state-specific time trend but older college graduates are significantly more likely when a state-specific time trend is included.

Table 6A reports OLS estimates of equation (2). The universe is all white men and women between the ages of 25 and 85 . The dependent variable is weeks worked. The controls in these regressions are dummies for married and high school graduate, and a set of age dummies, state dummies, and year dummies. Regressions are clustered on state. The coefficients of interest are male*over50*havelaw, which is the interaction of the observation being male, age 50 or over, and being in a state with a law, and male* under $50 *$ havelaw, which is the interaction of the observation being male, under the age of 50, and being in a state with a law. Women are less likely to sue under age discrimination laws than men, and as explained above, men in states with laws have less of a hurdle to suing than men in states without laws.

The results in Table 6A agree substantially with the Differences in Differences results for older men using having a law as identification in Table 2. There is still no significant effect of laws for either group prior to the discussion of federal enforcement of the law. In the later period, the magnitude for older men is somewhat larger than the largest estimate in Table 2, with men in states with laws working almost 1.7 fewer weeks, using women and not having a law as controls. Whereas the triple difference for men under the age of 50 is negative here, in the earlier calculation its sign depended on the inclusion of state trends, though again it is not statistically significant. 
Table 6B reports OLS estimates of equation (3). The universe is white men between the ages of 25 and 85 . The dependent variable is weeks worked. The controls in these regressions are dummies for married and high school graduate, and a set of age dummies, state dummies, and year dummies. Regressions are clustered on state. The coefficient of interest is havelaw*over50, which is the interaction of the observation being age 50 or over and being in a state with a law. These results also find a negative effect on weeks worked for older workers, with older workers working about 1.5 fewer weeks in states with laws. These results are within the bounds of those found by equation (1) presented in Table 2, Panel A.

On average, there is little clear evidence of an age discrimination law effect on the relative wages of older workers. Therefore, the rest of this paper focuses on a further investigation of the employment and labor force participation effects, and the analysis is limited to the demographic groups for which the evidence for employment effects is strongest — white men between the ages of 25 and 85 .

\section{Endogeneity of state laws}

To test for the possible endogeneity of state laws and pre-trends, in addition to adding state and year effects and trends, I run a specification check looking at the weeks worked outcome at a point five years before each state law was passed. The assumption is that employers do not know that a law will be passed prohibiting age discrimination five years prior to the law. No evidence is found that having a law five years in the future affects employment or hiring of either older or younger workers in the current period. The coefficient for weeks worked per year for older workers ranges from -0.091 (with no controls) with a standard error (SE) of 0.836 to -0.529 (with controls and a state trend) 
with an SE of 0.714. Coefficients for younger workers range from -0.330 with an SE of (0.570) to 0.310 with an SE of (0.824). Thus there is no evidence, using this test, that the introduction of state laws is related to something that directly affects the differential employment of older and younger workers. ${ }^{30}$

\subsection{The Impact of Age Discrimination Laws on Hiring and Separations}

Workers may also be working fewer weeks per year not just because they are more likely to retire but also because they are having difficulty finding work once they have separated from a previous job. Additionally, the law may be helping workers by decreasing firings and layoffs for older workers, because employers do not want to be sued. I used matched CPS rotations groups for the entire year to investigate the effect of age discrimination laws on hiring and separation rates (see Bleakley et al. (1999) for a detailed description of the match). An accession (hire) is recorded when someone who was not employed in month $m$ is employed in month $m+1$. Similarly, an individual is coded as having experienced a separation in month $m$ if he is employed in any month $m$ and not in month $m+1$ (individuals employed in December and not in January are coded as hired or separated in the January year). This definition includes people who move from being employed to no longer being in the labor force as separated, and thus captures those who have voluntarily retired in addition to those subject to layoffs, fires, and other quits. Neither hires nor separations include people who change jobs without leaving

\footnotetext{
${ }^{30}$ Some may worry that since states in the South are later adopters and migrant retirees often retire to the South that my results may be biased towards finding no result. However, the states with the largest inmigration are not the same as the states that are late adopters. Specifically, according to the census, the top 10 states receiving in-migrants are: 1970: FL, CA, AZ, NJ, TX, NY, OH, IL, PA, MO; 1980: FL, CA, AZ, TX, NY, PA, NC, WA, IL, NY; and 1990: FL, CA, AZ, TX, NC, PA, NJ, WA, VA, GA (Flynn et al. 1985, Longino 1995). As can be seen in Figure 2, these have a wide range of dates for law introduction.
} 
employment. ${ }^{31}$ These measures of accessions and separations are the same as those used by Bleakley et al. (1999).

As theory would predict, I find that older workers in states with laws are less likely to be hired than are workers in states without laws. I also find that workers are less likely to be separated from their jobs, though these results are not statistically significant. Results of a probit using equation (2) with Hired and Separated as outcome variables can be found in Table 7 . Workers over the age of 50 in states with discrimination laws are 2 to .3 percentage points less likely to be hired than workers in states without such laws. ${ }^{32}$ There is also a small but not statistically significant (once controls are added) positive effect on hiring for workers under the age of 50 in these states. Results on job separations are not as clear. There is a trend of reduced job separations for workers over the age of 50 in states with laws and increased job separations for workers under the age of 50, but these results are not significant at the 5 percent level. Because separations include retirements, which are more likely for older workers in states with age discrimination laws, I should be picking up two separate effects: increased retirement incentives and decreased firing and layoffs. ${ }^{33}$ Still, I find that older workers in states with laws are .1 percentage points less likely to be separated than workers in states without, and this effect is probably a lower bound. ${ }^{34}$

\footnotetext{
${ }^{31}$ Because older workers may be more likely to be unemployed before finding a new job (Diamond and Hausman 1984), this definition may overestimate older "hires" and "separations" and underestimate younger "hires" and "separations."

${ }^{32}$ The base for hired is 1.7 percentage points, and 1.8 and 1.5 for younger and older workers respectively.

${ }^{33}$ Simply limiting to people who do not say they are retired will not fix this effect because many people who are actually unemployed would call themselves retired for status reasons (Choi 2002).

${ }^{34}$ The base for separated is 1.9 percentage points for the universe regardless of age category.
} 


\section{Concluding Comments}

Employment of workers over the age of 50 has dropped since the ADEA was enforced in 1979. This drop is greater for workers in states where lawsuits are less of a hurdle for older workers, i.e., those states with their own age discrimination laws. Workers over the age of 50 in states with laws work between 1 and 1.5 fewer weeks per year than do workers in states without laws. Because, on average, older workers work 26.7 weeks per year and all workers work 45.5 weeks per year, ease of age discrimination lawsuit explains 5 to 8 percent of the gap in working weeks between older workers in states with laws and the general population. This drop in weeks worked may seem high, but it is comparable to the effect that Acemoglu and Angrist (2001) find for the disabled after the introduction of the Americans with Disabilities Act (ADA) in 1991, where weeks worked for disabled men falls 1.4 weeks in 1993 and another 1.5 weeks between 1993 and 1995.

Retirement has also increased for these older workers. Older workers in states with discrimination laws are .3 percentage points more likely to consider themselves retired than are workers in states without such laws. Hiring has decreased significantly for older workers in states where it is easier to sue; older workers are .2 percentage points less likely to be hired in states with age discrimination laws. Finally, separations have dropped, though not at a significant level.

I find no statistically significant decline in the employment or retirement for younger workers, non-white workers, and female workers based on state-time variation in ease of age discrimination lawsuit. A possible explanation for the difference in findings by race and gender is that before the advent of the ADEA, female and minority workers 
were already protected by the Civil Rights Act (CRA), which allows for more damages; white men over the age of 50 are the most likely to sue under the ADEA. Additionally, since these groups are not as strongly attached to the labor market, employers may think that they will leave their jobs before possible productivity declines due to age become an issue.

I also find no negative effects on older workers in the earlier period prior to enforcement. Although my results for this period are for the most part not statistically significant, my findings are not inconsistent with those in earlier work such as Adams (2004) or Neumark and Stock (1999). It may be that before the publicity surrounding the enforcement of the federal law, firms did not put the probability of lawsuit into their hiring calculations so that older white male job applicants were not harmed.

Since the ADEA provides a form of employment protection, it should lead to a lower separation rate for older workers. There does seem to be a protection benefit of this sort, although the results are not conclusive. However, there is also a large effect on increased retirements for these older workers. Employers appear to be reacting to age discrimination legislation and threats of lawsuits by failing to hire older workers, being less likely to fire or lay-off older workers but trying to remove older workers through retirement incentives. In general, it appears that these age protection laws have had very little effect on workers under the age of 50. 


\section{Works Cited}

Acemoglu, D. and J. D. Angrist (2001). “Consequences of Employment Protection? The Case of the Americans with Disabilities Act.” Journal of Political Economy 109(5): 915-57.

Adams, S. J. (2004). “Age Discrimination Legislation and the Employment of Older Workers.” Labour Economics 11(2): 219-41.

Ashenfelter, O. and D. Card (2002). "Did the Elimination of Mandatory Retirement Affect Faculty Retirement?” American Economic Review 92(4): 957-80.

Bleakley, H., A. E. Ferris, et al. (1999). "New data on worker flows during business cycles.” New England Economic Review(0): 49-76.

Butrica, B., K. E. Smith and C. E. Steuerle (2006). "Working for a Good Retirement." The Urban Institute Retirement Project Discussion Paper Series 06-03: 1-42.

Chan, S. and A. H. Stevens (1999). "Employment and Retirement Following a LateCareer Job Loss.” American Economic Review, 89(2): 211-16.

Chan, S. and A. H. Stevens (2001). "Job Loss and Employment Patterns of Older Workers.” Journal of Labor Economics, 19(2): 484-521.

Chan, S. and A. H. Stevens (2004). "Do Changes in Pension Incentives Affect Retirement? A Longitudinal Study of Subjective Retirement Expectations.” Journal of Public Economics, 88(7-8): 1307-33.

Chen, A. S. (2005). "The Party of Lincoln and the Politics of State Fair Employment Practices Legislation in the North, 1945-1964." Under review.

Choi, N. G. (2002). "Self-defined retirement status and engagement in paid work among older working-age women: comparison between childless women and mothers.” Sociological Inquiry 72(1): 43-71 Sociol Inq United States.

DeLeire, T. (2000). "The Wage and Employment Effects of the Americans with Disabilities Act.” Journal of Human Resources 35(4): 693-715.

Diamond, P. A. and J. A. Hausman (1984). The Retirement and Unemployment Behavior of Older Men. Retirement and Economic Behavior. H. J. Aaron. Studies in Social Economics series Washington, D.C., Brookings Institution: 97-132.

Donohue, J. J. and P. a. B. F. Siegelman (1990). The changing nature of employment discrimination litigation. Chicago, Ill., American Bar Foundation.

Flynn, C.B, C.F. Longino, R.F. Wiseman, and J.C. Biggar (1985). “The Redistribution of America's Older Population: Major National Migration Patterns for Three Census Decades 1960-1980.” The Gerontologist 25(3):292-6.

Gregory, R. F. (2001). Age Discrimination in the American Workplace: Old at a Young Age. New Brunswick, Rutgers University Press.

Gruber, J. (1994). “The Incidence of Mandated Maternity Benefits.” American Economic Review 84(3): 622-41.

Hersch, J. (2006). "Demand for a Jury Trial and the Selection of Cases for Trial." Journal of Legal Studies 35(1): 119-142.

Hersch, J. and W.K. Viscusi (2004). "Punitive Damages: How Judges and Juries Perform.” Journal of Legal Studies 33(1): 1-36.

Hutchens, R. M. (1988). “Do Job Opportunities Decline with Age?” Industrial and Labor Relations Review 42(1): 89-99. 
Jolls, C. (1996). "Hands-Tying and the Age Discrimination in Employment Act” $\underline{74}$ Texas Law Review 1813: 1-27.

Jolls, C. and J. J. Prescott (2004). "Disaggregating Employment Protection: The Case of Disability Discrimination.” National Bureau of Economic Research, Inc, NBER Working Papers:

Lahey, J. (2005). “Age, Women, and Hiring: An Experimental Study.” National Bureau of Economic Research Working Paper: 11435.

Levine, M. L. (1988). Age discrimination and the mandatory retirement controversy. Baltimore and London, Johns Hopkins University Press.

Lindemann, B. T. and D. D. Kadue (2003). Age Discrimination in Employment Law. Portland, OR, B N A Books.

Longino, C.F. (1995). Retirement Migration in America. Houston, Vacation Publications.

Mitchell, O. S. and R. A. Luzadis (1988). "Changes in Pension Incentives through Time.” Industrial and Labor Relations Review 42(1): 100-108.

Munk, N. (1999). Finished at forty. Fortune, 139: 50-66.

Neumark, D. (2001). Age Discrimination Legislation in the United States. National Bureau of Economic Research Working Paper: 35.

Neumark, D. and W. A. Stock (1999). "Age Discrimination Laws and Labor Market Efficiency.” Journal of Political Economy 107(5): 1081-1125.

O'Meara, D. P. (1989) Protecting the Growing Number of Older Workers: The Age Discrimination in Employment Act. Philadelphia, Pennsylvania, University of Pennsylvania.

Schuster, M. and C. S. Miller (1984). "An Empirical Assessment of the Age Discrimination in Employment Act.” Industrial and Labor Relations Review 38(1): 64-74.

Stock, W. A. and K. Beegle (2004). "Employment Protections for Older Workers: Do Disability Discrimination Laws Matter?" Contemporary Economic Policy 22(1): 111-126.

US Department of Labor (1965) "The Older American Worker, Age Discrimination in Employment", Report of the Secretary of Labor to the Congress Under Section 715 of the Civil Rights Act of 1964: June.

von Wachter, T. (2002). The End of Mandatory Retirement in the US: Effects on Retirement and Implicit Contracts. University of California, Berkeley, The Center for Labor Economics Working Paper: 35. 
TABLE 1

Descriptive Statistics for White Men by Age Group and Law Status

\begin{tabular}{|c|c|c|c|c|c|c|c|c|c|c|}
\hline & $\begin{array}{c}25-34 \\
(1) \\
\end{array}$ & $\begin{array}{c}35-44 \\
(2) \\
\end{array}$ & $\begin{array}{c}45-54 \\
(3) \\
\end{array}$ & $\begin{array}{c}45-49 \\
(4) \\
\end{array}$ & $\begin{array}{c}50-54 \\
(5) \\
\end{array}$ & $\begin{array}{c}55-64 \\
(6) \\
\end{array}$ & $\begin{array}{c}65-74 \\
(7) \\
\end{array}$ & $\begin{array}{c}75-84 \\
(8) \\
\end{array}$ & $\begin{array}{c}\text { Have Law } \\
(9)\end{array}$ & $\begin{array}{c}\text { No Law } \\
(10) \\
\end{array}$ \\
\hline & \multicolumn{10}{|c|}{ A. $1968-1977$} \\
\hline age & 29.22 & 39.54 & 49.43 & 47.00 & 51.97 & 59.21 & 68.96 & 78.52 & 47.35 & 47.83 \\
\hline employed & 0.92 & 0.94 & 0.91 & 0.92 & 0.90 & 0.77 & 0.29 & 0.12 & 0.79 & 0.78 \\
\hline unemployed & 0.04 & 0.03 & 0.03 & 0.03 & 0.03 & 0.03 & 0.01 & 0.00 & 0.03 & 0.02 \\
\hline married & 0.79 & 0.87 & 0.88 & 0.87 & 0.89 & 0.86 & 0.81 & 0.71 & 0.82 & 0.86 \\
\hline weeks worked & 44.64 & 46.36 & 45.90 & 46.41 & 45.36 & 40.35 & 16.63 & 7.19 & 39.97 & 39.03 \\
\hline high school grad & 0.81 & 0.71 & 0.62 & 0.64 & 0.60 & 0.49 & 0.35 & 0.26 & 0.64 & 0.58 \\
\hline wage income & $19,160.54$ & $22,415.62$ & $21,130.20$ & $21,839.40$ & $20,392.89$ & $16,138.39$ & $3,581.64$ & 864.10 & $18,487.63$ & $15,097.51$ \\
\hline weekly wage & 415.12 & 470.15 & 456.49 & 465.41 & 447.03 & 398.53 & 225.50 & 123.54 & 453.72 & 374.46 \\
\hline In(weekly wage) & 5.95 & 6.11 & 6.09 & 6.10 & 6.07 & 5.95 & 5.24 & 4.78 & 6.05 & 5.86 \\
\hline retired & 0.00 & 0.00 & 0.01 & 0.00 & 0.01 & 0.05 & 0.48 & 0.69 & 0.09 & 0.09 \\
\hline \multirow[t]{2}{*}{ Observations } & 80,877 & 68,747 & 70,003 & 35,595 & 34,408 & 55,595 & 34,721 & 15,553 & 164,904 & 50,549 \\
\hline & \multicolumn{10}{|c|}{ B. 1978-1991 } \\
\hline age & 29.42 & 39.18 & 49.38 & 46.94 & 51.98 & 59.37 & 69.01 & 78.50 & 46.37 & 46.66 \\
\hline employed & 0.89 & 0.91 & 0.88 & 0.89 & 0.86 & 0.67 & 0.22 & 0.09 & 0.74 & 0.77 \\
\hline unemployed & 0.06 & 0.05 & 0.04 & 0.04 & 0.04 & 0.03 & 0.01 & 0.00 & 0.04 & 0.03 \\
\hline married & 0.62 & 0.78 & 0.83 & 0.82 & 0.84 & 0.85 & 0.82 & 0.74 & 0.75 & 0.81 \\
\hline weeks worked & 44.77 & 46.24 & 45.30 & 46.01 & 44.54 & 35.81 & 11.85 & 4.82 & 38.23 & 38.80 \\
\hline high school grad & 0.87 & 0.85 & 0.77 & 0.79 & 0.74 & 0.68 & 0.56 & 0.43 & 0.77 & 0.70 \\
\hline wage income & $16,586.65$ & $21,652.52$ & $21,509.51$ & $22,144.00$ & $20,831.13$ & $15,329.23$ & $2,928.75$ & 752.65 & $16,246.72$ & $15,037.89$ \\
\hline weekly wage & 358.33 & 455.66 & 467.73 & 473.73 & 461.12 & 427.48 & 249.05 & 153.54 & 413.97 & 373.69 \\
\hline In(weekly wage) & 5.77 & 6.03 & 6.08 & 6.09 & 6.07 & 5.96 & 5.20 & 4.75 & 5.91 & 5.84 \\
\hline retired & 0.000 & 0.001 & 0.010 & 0.005 & 0.015 & 0.130 & 0.601 & 0.775 & 0.13 & 0.11 \\
\hline Observations & 150,194 & 119,063 & 95,009 & 57,414 & 48,748 & 80,812 & 57,522 & 25,208 & 501,941 & 55,740 \\
\hline
\end{tabular}

NOTE: Years refer to survey years. Statistics are weighted using CPS person weights. Income is inflated/deflated to $1982-1984$ dollars using the CPI. Summary statistics are taken from the IPUMS CPS, except for data on retirement which is from the Unicon set. 


\section{Figure 1: Weeks Worked Per Year}

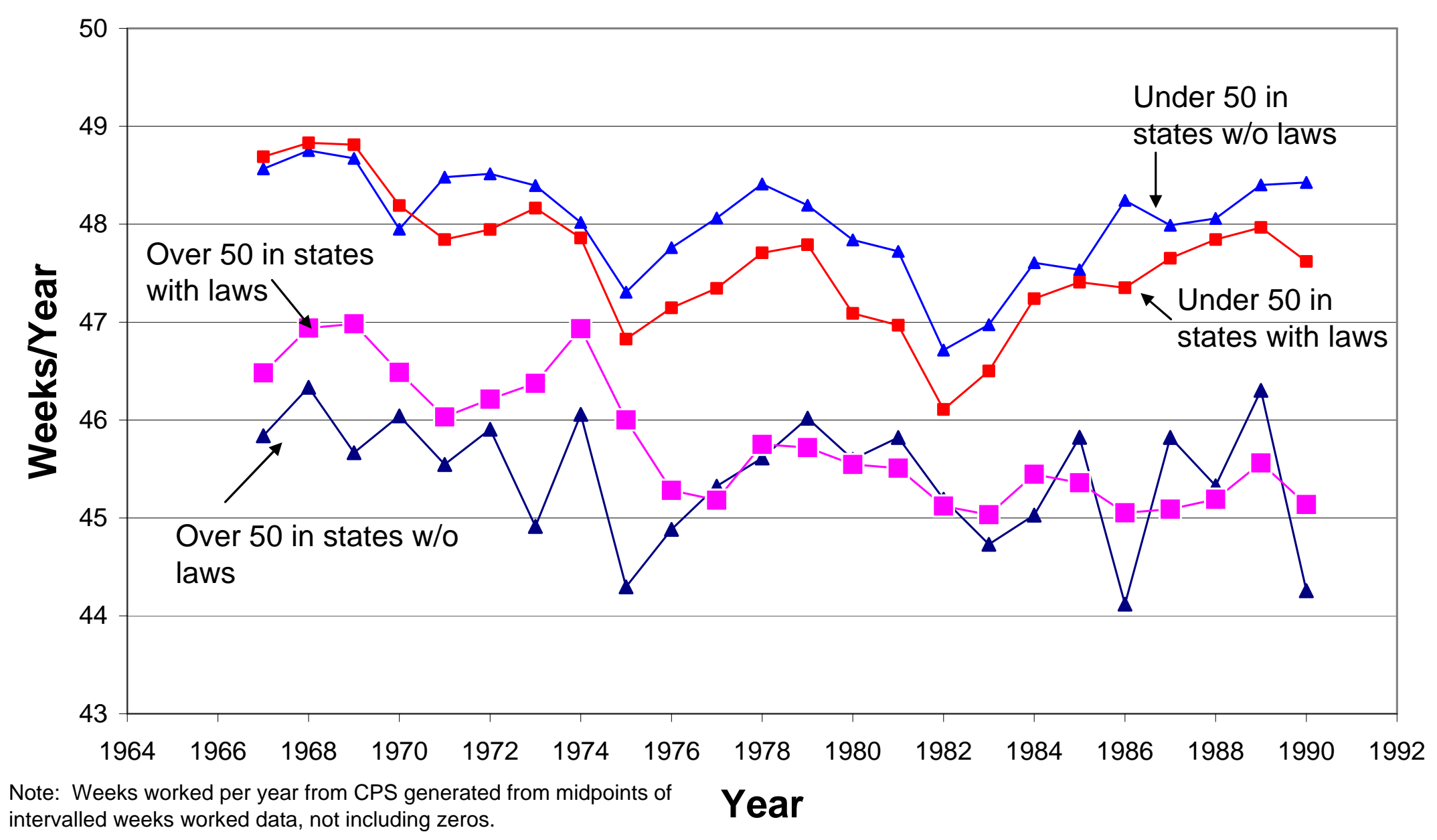


Figure 2: Year of implementation of State Law (1900s)

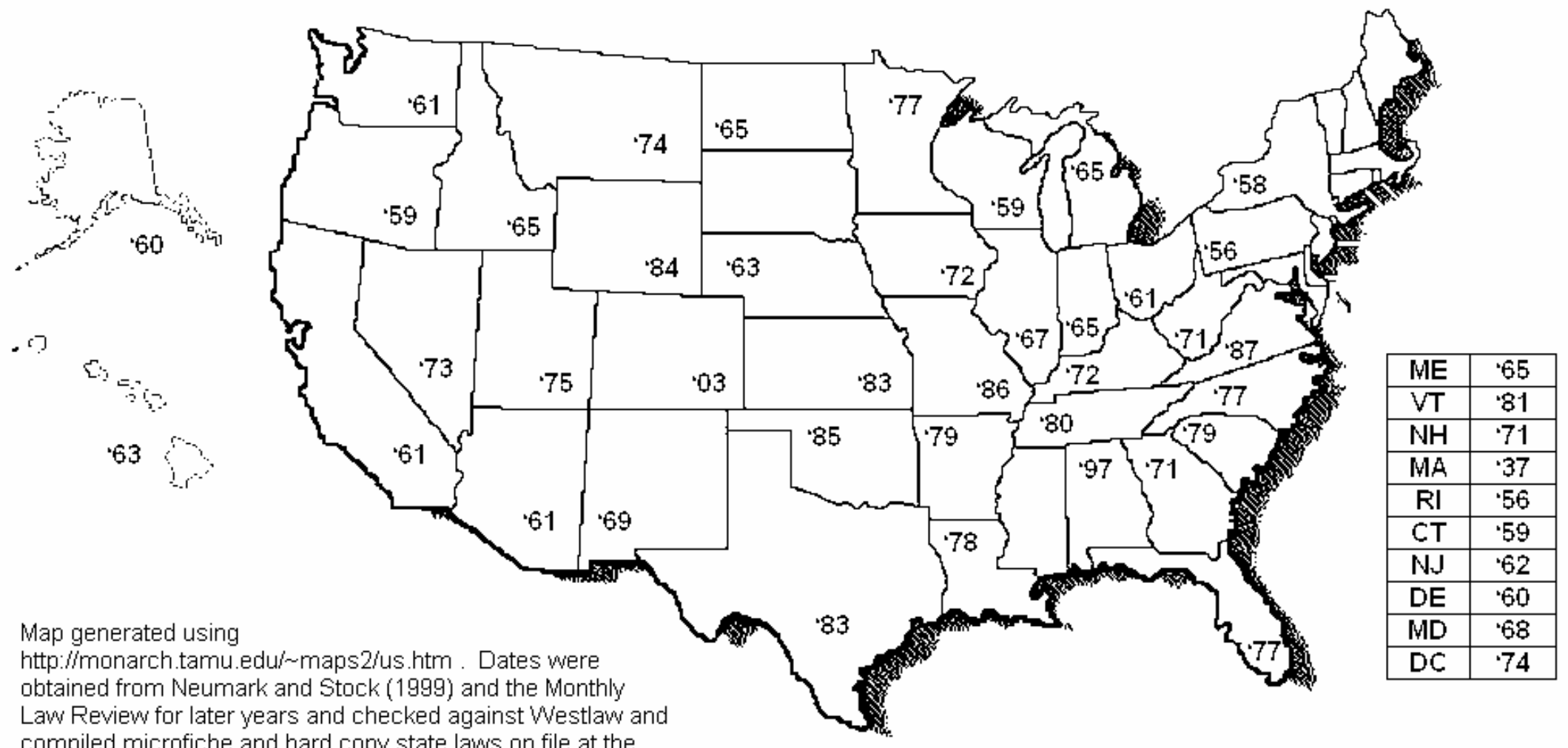

complew for later years and checked against Westlaw anc

Harvard Law Library. 
TABLE 2

Initial Results

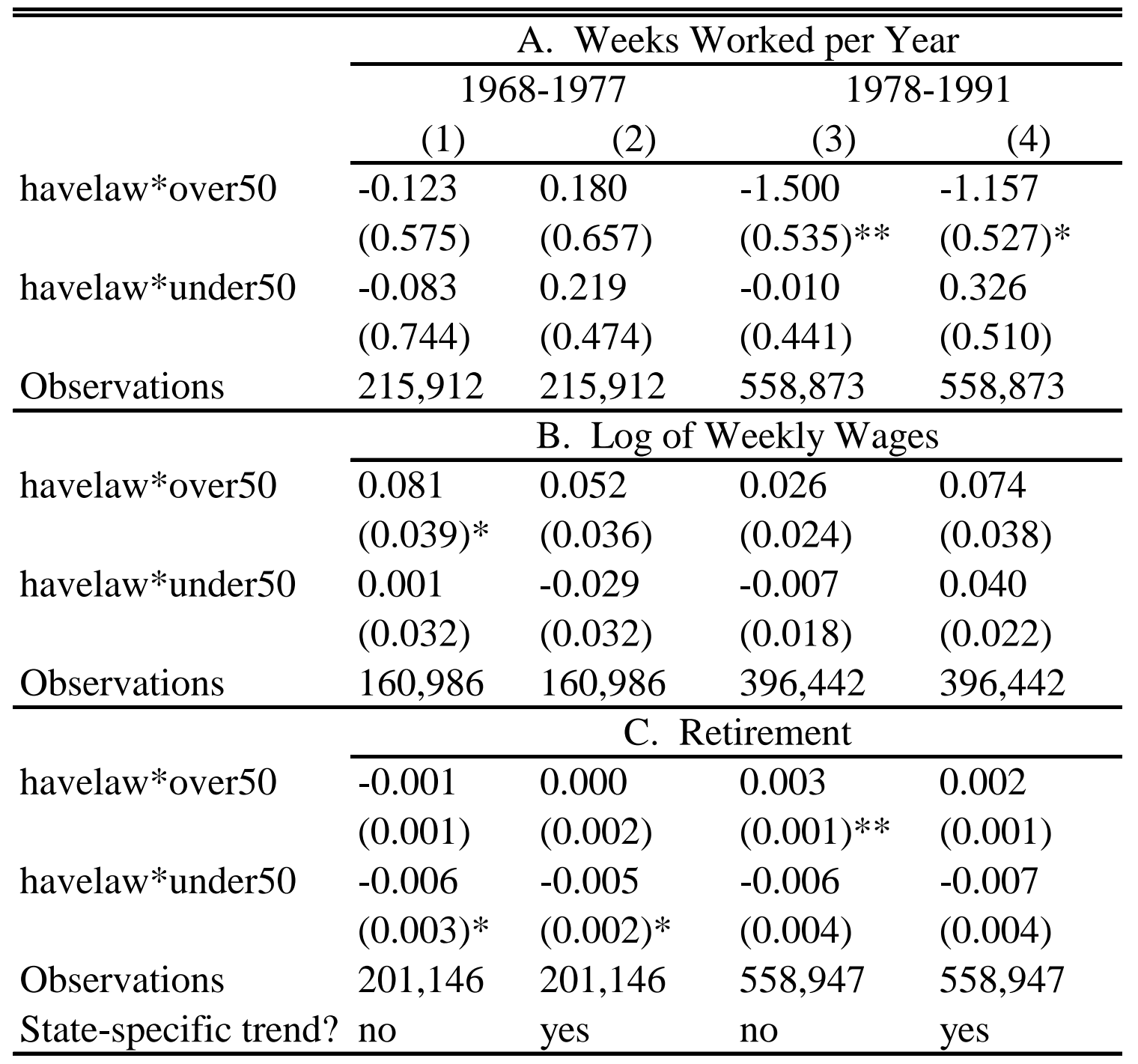

NOTES. -- Standard errors are reported in parentheses and clustered on state. The table reports OLS havelaw * over 50 interactions in regressions that include married, high school graduate, age dummies, year dummies, and state dummies. The marginal of the Probit coefficient is reported in panel C. Universe includes all white men age 25 to 85 . Years in charts refer to survey year. Weeks worked and wage information refer to the previous year, thus Weeks 1967-1976 and 1977-1990. 
TABLE 3

Results by Varying Enforcement Year

\begin{tabular}{lllll}
\hline \hline & \multicolumn{4}{c}{ A. Weeks Worked per Year } \\
\cline { 2 - 5 } & \multicolumn{2}{c}{$1979-1991$} & \multicolumn{2}{c}{$1980-1991$} \\
havelaw*over50 & -1.396 & -0.874 & -1.399 & -0.817 \\
& $(0.564)^{*}$ & $(0.519)$ & $(0.619)^{*}$ & $(0.541)$ \\
havelaw*under50 & -0.036 & 0.484 & -0.111 & 0.474 \\
& $(0.462)$ & $(0.468)$ & $(0.525)$ & $(0.425)$ \\
Observations & 521,946 & 521,946 & 485,330 & 485,330 \\
\hline \multirow{4}{*}{ havelaw*over50 } & 0.021 & 0.077 & 0.010 & 0.064 \\
& $(0.024)$ & $(0.042)$ & $(0.024)$ & $(0.042)$ \\
havelaw*under50 & -0.015 & 0.041 & -0.019 & 0.034 \\
& $(0.021)$ & $(0.024)$ & $(0.025)$ & $(0.028)$ \\
Observations & 369,888 & 369,888 & 343,676 & 343,676 \\
\hline \multirow{4}{*}{ C. Retirement } \\
havelaw*over50 & 0.003 & 0.001 & 0.003 & 0.001 \\
& $(0.001)^{* *}$ & $(0.001)$ & $(0.001)^{*}$ & $(0.001)$ \\
havelaw*under50 & -0.007 & -0.008 & -0.007 & -0.008 \\
& $(0.004)$ & $(0.005)$ & $(0.004)$ & $(0.005)$ \\
Observations & 522,020 & 522,020 & 485,371 & 485,371 \\
State-specific trend? & no & yes & no & yes \\
\hline
\end{tabular}

NOTES. -- Standard errors are reported in parentheses and clustered on state. The table reports OLS havelaw * over 50 interactions in regressions that include married, high school graduate, age dummies, year dummies, and state dummies. The marginal of the Probit coefficient is reported in panel C. Universe includes all white men age 25 to 85. Years in charts refer to survey year. Weeks worked and wage information refer to the previous year, thus 1978-1990 and 19791990. 
TABLE 4

Results by Varying Top Age Tail: 1978-1991

\begin{tabular}{|c|c|c|c|c|c|c|}
\hline & \multicolumn{6}{|c|}{ A. Weeks Worked per Year } \\
\hline & \multicolumn{2}{|c|}{$25-59$} & \multicolumn{2}{|c|}{$25-64$} & \multicolumn{2}{|c|}{$25-74$} \\
\hline & $(1)$ & $(2)$ & (3) & $(4)$ & (5) & $(6)$ \\
\hline \multirow[t]{2}{*}{ havelaw*over50 } & -0.429 & -0.374 & -0.788 & -0.540 & -1.458 & -1.102 \\
\hline & (0.459) & $(0.462)$ & $(0.545)$ & $(0.544)$ & $(0.542)^{* *}$ & $(0.571)$ \\
\hline \multirow[t]{2}{*}{ havelaw*under50 } & -0.303 & -0.240 & -0.151 & 0.097 & -0.051 & 0.301 \\
\hline & $(0.427)$ & $(0.376)$ & $(0.442)$ & $(0.432)$ & $(0.434)$ & $(0.519)$ \\
\hline \multirow[t]{2}{*}{ Observations } & 427,774 & 427,774 & 469,308 & 469,308 & 530,760 & 530,760 \\
\hline & \multicolumn{6}{|c|}{ B. Log of Weekly Wages } \\
\hline \multirow[t]{2}{*}{ havelaw*over50 } & 0.013 & 0.063 & 0.024 & 0.074 & 0.025 & 0.075 \\
\hline & $(0.026)$ & $(0.030) *$ & $(0.023)$ & $(0.033) *$ & $(0.024)$ & $(0.038)$ \\
\hline \multirow[t]{2}{*}{ havelaw*under50 } & -0.009 & 0.040 & -0.007 & 0.043 & -0.005 & 0.044 \\
\hline & $(0.018)$ & $(0.015)^{*}$ & $(0.019)$ & $(0.019) *$ & $(0.018)$ & $(0.021)^{*}$ \\
\hline \multirow[t]{2}{*}{ Observations } & 356,807 & 356,807 & 380,009 & 380,009 & 394,207 & 394,207 \\
\hline & \multicolumn{6}{|c|}{ C. Retirement } \\
\hline \multirow[t]{2}{*}{ havelaw*over50 } & -0.0000 & 0.0001 & 0.0002 & -0.0002 & 0.0019 & 0.0008 \\
\hline & $(0.0003)$ & $(0.0004)$ & $(0.0003)$ & $(0.0005)$ & $(0.0006)^{*}$ & $:(0.0011)$ \\
\hline \multirow[t]{2}{*}{ havelaw*under50 } & -0.0008 & -0.0006 & -0.0017 & -0.0022 & -0.0040 & -0.0050 \\
\hline & $(0.0008)$ & $(0.0008)$ & $(0.0013)$ & $(0.0012)$ & $(0.0029)$ & $(0.0030)$ \\
\hline Observations & 427,830 & 427,830 & 469,374 & 469,374 & 530,829 & 530,829 \\
\hline State-specific trend & no & yes & no & yes & no & yes \\
\hline
\end{tabular}

NOTES. -- Standard errors are reported in parentheses and clustered on state. The table reports OLS havelaw * over 50 interactions in regressions that include married, high school graduate, age dummies, year dummies, and state dummies. The marginal of the Probit coefficient is reported in panel C. Universe includes all white men. Years in charts refer to survey year. Weeks worked and wage information refer to the previous year, thus 1977-1990.

* significant at $5 \%$;** significant at $1 \%$ 
TABLE 5

Results by Varying Gender, Race, and Education of Universe, 1978-1991

\begin{tabular}{|c|c|c|c|c|c|c|c|c|}
\hline & \multicolumn{8}{|c|}{ A. Weeks Worked per Year } \\
\hline & \multicolumn{2}{|c|}{ White Women } & \multicolumn{2}{|c|}{ Black Men } & \multicolumn{2}{|c|}{ Not College Grad } & \multicolumn{2}{|c|}{ College Grad } \\
\hline & $(1)$ & $(2)$ & (3) & (4) & (5) & (6) & $(7)$ & (8) \\
\hline \multirow[t]{2}{*}{ havelaw*over50 } & -0.881 & -0.130 & -0.547 & -0.040 & -1.495 & -0.949 & -1.068 & -1.583 \\
\hline & $(0.556)$ & $(0.389)$ & $(0.927)$ & $(0.738)$ & $(0.490)^{* *}$ & $(0.548)$ & $(0.806)$ & $(0.723)^{*}$ \\
\hline \multirow[t]{2}{*}{ havelaw*under50 } & -0.068 & 0.691 & -0.359 & 0.061 & -0.167 & 0.367 & 0.459 & -0.067 \\
\hline & $(0.216)$ & $(0.493)$ & $(0.788)$ & $(0.608)$ & $(0.386)$ & $(0.564)$ & $(0.626)$ & $(0.617)$ \\
\hline \multirow[t]{2}{*}{ Observations } & 620,885 & 620,885 & 67,596 & 67,596 & 427,817 & 427,817 & 131,056 & 131,056 \\
\hline & \multicolumn{8}{|c|}{ B. Log of Weekly Wages } \\
\hline \multirow[t]{2}{*}{ havelaw*over50 } & 0.004 & 0.028 & 0.099 & 0.210 & 0.02 & 0.058 & 0.02 & 0.096 \\
\hline & $(0.019)$ & $(0.027)$ & $(0.063)$ & $(0.055)^{* *}$ & $(0.021)$ & $(0.031)$ & $(0.036)$ & $(0.070)$ \\
\hline \multirow[t]{2}{*}{ havelaw*under50 } & -0.012 & 0.010 & -0.043 & 0.064 & -0.018 & 0.020 & 0.004 & 0.081 \\
\hline & $(0.014)$ & $(0.021)$ & $(0.051)$ & $(0.028) *$ & $(0.019)$ & $(0.016)$ & $(0.021)$ & $(0.052)$ \\
\hline \multirow[t]{2}{*}{ Observations } & 327,164 & 327,164 & 47,468 & 47,468 & 290,414 & 290,414 & 106,028 & 106,028 \\
\hline & \multicolumn{8}{|c|}{ C. Retirement } \\
\hline \multirow[t]{2}{*}{ havelaw*over50 } & 0.001 & 0.001 & 0.002 & 0.001 & 0.003 & 0.002 & 0.002 & 0.003 \\
\hline & $(0.001)$ & $(0.001)$ & $(0.002)$ & $(0.003)$ & $(0.001)^{* *}$ & $(0.002)$ & $(0.001)$ & $(0.002)^{*}$ \\
\hline \multirow[t]{2}{*}{ havelaw*under50 } & -0.008 & -0.008 & -0.010 & -0.011 & -0.011 & -0.012 & 0.001 & 0.002 \\
\hline & $(0.002)^{* *}$ & $(0.002)^{* *}$ & $(0.005)^{*}$ & $(0.006)$ & $(0.006)$ & $(0.006)^{*}$ & $(0.002)$ & $(0.002)$ \\
\hline Observations & 605,027 & 605,027 & 62,963 & 62,963 & 429,678 & 429,678 & 109,059 & 109,059 \\
\hline \multicolumn{2}{|c|}{ State-specific trend? no } & yes & no & yes & no & yes & no & yes \\
\hline
\end{tabular}

NOTES. -- Standard errors are reported in parentheses and clustered on state. The table reports OLS havelaw * over 50 interactions in regressions that include married, high school graduate, age dummies, year dummies, and state dummies. The marginal of the Probit coefficient is reported in panel C. Years in charts refer to survey year. Weeks worked and wage information refer to the previous year, thus 1977-1990. Universe includes people between the ages of 25 and 85 inclusive. Not College Grad and Collge Grad columns are white men only.

* significant at 5\%; ** significant at $1 \%$ 
TABLE 6

Alternative Identification Strategies

Weeks Worked

\begin{tabular}{|c|c|c|c|c|}
\hline & \multicolumn{4}{|c|}{ A. D-D-D Women and Havelaw } \\
\hline & \multicolumn{2}{|c|}{$1968-1977$} & \multicolumn{2}{|c|}{$1978-1991$} \\
\hline & $(1)$ & $(2)$ & $(3)$ & $(4)$ \\
\hline \multirow{2}{*}{ male*over $50 *$ havelaw } & 0.366 & 0.366 & -1.710 & -1.708 \\
\hline & $(0.673)$ & $(0.674)$ & $(0.557)^{* *}$ & $(0.555)^{* *}$ \\
\hline \multirow[t]{2}{*}{ male*under50*havelaw } & 1.347 & 1.348 & -1.569 & -1.566 \\
\hline & $(0.911)$ & $(0.912)$ & $(0.913)$ & $(0.912)$ \\
\hline \multirow[t]{2}{*}{ male*over50 } & 15.820 & 15.818 & 12.476 & 12.474 \\
\hline & $(0.671)^{* *}$ & $(0.671)^{* *}$ & $(0.553)^{* *}$ & $(0.550) * *$ \\
\hline \multirow[t]{2}{*}{ male*under50 } & 21.468 & 21.467 & 14.356 & 14.353 \\
\hline & $(0.655) * *$ & $(0.655)^{* *}$ & $(0.831)^{* *}$ & $(0.830) * *$ \\
\hline \multirow[t]{2}{*}{ havelaw*over50 } & 0.250 & 0.248 & -0.359 & 0.147 \\
\hline & $(0.425)$ & $(0.388)$ & $(0.379)$ & $(0.399)$ \\
\hline \multirow[t]{2}{*}{ havelaw*under50 } & -1.058 & -1.057 & 0.752 & 1.258 \\
\hline & $(0.831)$ & $(0.754)$ & $(0.423)$ & $(0.787)$ \\
\hline \multirow[t]{2}{*}{ Observations } & 460,122 & 460,122 & $1,179,758$ & $1,179,758$ \\
\hline & \multicolumn{4}{|c|}{ B. Havelaw * Over50 with State*Time } \\
\hline \multirow[t]{2}{*}{ havelaw*over50 } & \multirow{2}{*}{\multicolumn{2}{|c|}{$\begin{array}{l}-0.036 \\
(0.875)\end{array}$}} & \multicolumn{2}{|c|}{-1.483} \\
\hline & & & $(0.637)^{*}$ & \\
\hline \multirow{2}{*}{$\begin{array}{l}\text { Observations } \\
\text { State-specific trend? }\end{array}$} & \multicolumn{2}{|l|}{215,912} & \multicolumn{2}{|l|}{558,873} \\
\hline & no & yes & no & yes \\
\hline
\end{tabular}

NOTES. -- Standard errors are reported in parentheses and clustered on state. Panel A reports OLS male * havelaw * over 50 interactions in regressions that include married, high school graduate, age dummies, year dummies, and state dummies. Panel A includes all white men and women age 25-85. Panel B reports OLS havelaw * over 50 interactions in regressions that include married, high school graduate, age dummies, year dummies, and state dummies. Panel B includes all white men age 25-85. Years in charts refer to survey year. Weeks worked refers to the previous year, thus 1967-1976 and 1977-1990.

* significant at $5 \%$;** significant at $1 \%$ 
TABLE 7

Results on Hiring/Separation Margins: 1978-1991

\begin{tabular}{lllll}
\hline \hline & \multicolumn{4}{c}{ A. Hired } \\
\cline { 2 - 5 } & \multicolumn{1}{c}{$(1)$} & \multicolumn{1}{c}{$(2)$} & \multicolumn{1}{c}{$(3)$} & \multicolumn{1}{c}{$(4)$} \\
havelaw* over50 & -0.0027 & -0.0022 & -0.0029 & -0.0023 \\
& $(0.0008)^{* *}$ & $(0.0008)^{* *}$ & $(0.0009)^{* *}$ & $(0.0010)^{*}$ \\
havelaw*under50 & 0.002 & 0.0018 & 0.0019 & 0.0017 \\
& $(0.0013)$ & $(0.0012)$ & $(0.0009)^{*}$ & $(0.0009)$ \\
Observations & 4351023 & 4351023 & 4351023 & 4351023 \\
\hline \multirow{4}{*}{ havelaw*over50 } & -0.0015 & -0.0009 & -0.0012 & -0.0006 \\
& $(0.0010)$ & $(0.0009)$ & $(0.0012)$ & $(0.0012)$ \\
havelaw*under50 & 0.0034 & 0.0031 & 0.0036 & 0.0034 \\
& $(0.0016)^{*}$ & $(0.0016)^{*}$ & $(0.0022)$ & $(0.0021)$ \\
Observations & 4351023 & 4351023 & 4351023 & 4351023 \\
Controls? & no & yes & no & yes \\
State-specific trend? no & no & yes & yes \\
\hline
\end{tabular}

NOTES. -- Standard errors are reported in parentheses and clustered on state. The table reports the marginal coefficient of havelaw * over 50 interactions in probits that include married, high school graduate, age dummies, year dummies, and state dummies. Marginal effects are reported. (OLS regressions look very similar). Universe includes all white men age 25 to 85 .

* significant at $5 \%$; ** significant at $1 \%$ 


\title{
RECENT WORKING PAPERS FROM THE \\ CENTER FOR RETIREMENT RESEARCH AT BOSTON COLLEGE
}

\author{
Age, Women, and Hiring: An Experimental Study \\ Joanna Lahey, November 2006 \\ Optimal Retirement Asset Decumulation Strategies: The Impact of Housing Wealth \\ Anthony Webb, Robert Triest, and Wei Sun, November 2006
}

The Impact of Aggregate Mortality Rise on Defined Benefit Pension Plans Irena Dushi, Leora Friedberg, and Anthony Webb, November 2006

Health Care Costs, Taxes, and the Retirement Decision: Conceptual Issues and Illustrative Simulations

Rudolph G. Penner and Richard W. Johnson, November 2006

Why Do Boomers Plan to Work So Long?

Gordon B.T. Mermin, Richard W. Johnson, and Dan Murphy, November 2006

Job Tenure and Pension Coverage

Alicia H. Munnell, Kelly Haverstick, and Geoffrey Sanzenbacher, October 2006

Has the Displacement of Older Workers Increased?

Alicia H. Munnell, Steven Sass, Mauricio Soto, and Natalia Zhivan, September 2006

No Place Like Home: Older Adults and their Housing

Timothy Smeeding, Barbara Boyle Torrey, Jonathan Fisher, David S. Johnson, and Joseph Marchand, August 2006

Effects of Public Policies on the Disposition of Lump-Sum Distributions: Rational and Behavioral Influences

William G. Gale and Michael Dworsky, August 2006

Pensions, Social Security, Wealth and Lifetime Earnings: Evidence from the Health and Retirement Study

William G. Gale and John W.R. Phillips, August 2006

Determinants and Consequences of Bargaining Power in Households

Leora Friedberg and Anthony Webb, June 2006

All working papers are available on the Center for Retirement Research website

(http://www.bc.edu/crr) and can be requested by e-mail (crr@bc.edu) or phone (617-552-1762). 